\title{
EXPLORING INTERPERSONAL COMMUNICATION ON AFFECTIVE COMMITMENT: CROSS SECTIONAL STUDY ON TEACHER PERSPECTIVE
}

\author{
Asmawati Asharie \\ Universitas Indo Global Mandiri, Palembang, Indonesia. \\ E-mail: asmawati.asharie@gmail.com
}

\begin{abstract}
This study intends to determine the effect of internal communication aspects on affective commitment. To determine the influence of the interpersonal communication aspect, the researcher used a survey of private high school teachers in Palembang City, South Sumatra. The number of respondents was as many as 137 teachers. To examine the effect of interpersonal communication aspects on affective commitment, researchers used multiple regression analysis techniques. The results showed that all aspects of interpersonal communication had a significant effect on teachers' affective commitment. In addition, the study results indicate that excellent openness, empathy, supportiveness, positiveness, and equality will impact teachers' affective commitment.
\end{abstract}

Keywords: interpersonal communication, affective commitment.

\section{INTRODUCTION}

The main challenge for the Indonesian nation is to prepare existing individuals to become solid and qualified human resources, not only to face current conditions but in the future to be able to face challenges that arise in the future. In this context, education plays an essential role in creating superior, resilient, and ready to compete for human resources in any condition, which is an aspect of intangible assets that plays an important role. (Sidharta \& Affandi, 2016)

In the world of education, starting from elementary level education, secondary level, even up to the level of higher education cannot be separated from the educator factor itself. In the context of primary and secondary education, the teacher is the main factor and determinant of the quality of the graduates it produces. (Kim \& Seo, 2018) Quality teachers are teachers who have good performance. The quality of these graduates is an indicator of the quality of the teachers in them. (Muhonen, Pakarinen, Poikkeus, Lerkkanen \& Rasku-Puttonen, 2018) 
In the context of secondary education, the quality of high school graduates is very influential on success in competing in the world of higher education. This means that graduates with better quality, of course, will have a higher probability in their efforts to win competitions in the world of higher education, in this case, are quality universities. (Ahmad, Shaharim \& Abdullah, 2017) One of the determinants of the quality of high school graduates is the quality of the teachers in it. Teachers must be able to improve their quality according to today's needs, even more so that they can prepare themselves to face future demands. The performance of this high school teacher must be able to adapt to the demands of present and future needs.

The factors that shape teacher performance must receive better attention to adapt to the present and the future, including the high teacher commitment factor that requires interpersonal communication. This factor plays an essential role in increasing the commitment of high school teachers, especially private high schools. Commitment in this study focuses on affective commitment. The measurement of affective commitment is based on the dimensions of emotional ability, problem identification, sense of attachment, sense of belonging, sense of pride, ability to see work conditions, and ability to work expected. The results of the pre-survey on commitment indicate that the condition of teacher commitment is still inadequate. This phenomenon is caused because the planning for setting goals or objectives to be achieved is too high, not proportional to the potential or capacity of private high school teachers. Another factor is that the level of discipline of the teachers in carrying out their duties as teachers and educators is still not optimal.

Furthermore, efforts to improve the results of implementing quality learning activities are to improve communication, especially communication between individuals in the organization, in this case, the school environment. (Ahmad, Shaharim \& Abdullah, 2017; Schatz-Oppenheimer, 2017) In secondary education, especially high school, interpersonal communication here is communication made by teachers. If interpersonal communication is well established, the hope is that the quality of teacher learning will increase. (Işik, 2020) Interpersonal communication occurs between two or more people directly (face to face), and there is direct reciprocity both verbally and non-verbally. (Hargie, 2016) Interpersonal communication is a communication process between two or more people face to face (Khan, Khan, Zia-Ul-Islam \& Khan, 2017).

Interpersonal communication is dialogical in the sense that the backflow between the communicator and the communicant occurs directly. At that time, the communicator can know the response from the communicant directly and will know whether the communication is positive, negative, and successful or not. (Hargie, 2016) To obtain effective communication, openness, empathy, supportiveness, positiveness, and equality are needed. (DeVito, 2013) Based on identifying problems where there is inadequate commitment and interpersonal communication of teachers, the researchers conducted a study to determine the effect of aspects of interpersonal communication on teachers' affective commitment. 


\section{METHOD}

Associative quantitative research method with causal study approach is the research method used in this study. This method analyzes the pattern of relationships between variables to know the direct or indirect effect of a set of independent or exogenous variables on the dependent or endogenous variables using multiple regression techniques. The category of this research is cross-sectional. That is, information from part of the population (sample of respondents) is collected directly from the location empirically to know the opinion of some of the population on the object under study. Respondents were 137 teachers in the city of Palembang, South Sumatra.

The operational variable in this study is interpersonal communication, which is verbal and nonverbal interaction between two (or more than two) people who depend on each other. (DeVito, 2013) As for interpersonal communication, namely Openness, Empathy, Supportive Attitude, Positive Attitude, and Harmony. At the same time, affective commitment refers to the approach used by Meyer \& Allen (2001).

Validity shows how the questionnaire, in this case, the question items or questions, has measured what will be measured. This means that the instrument or measuring instrument is following what will be measured. Validity was measured by using the correlation technique between item scores and total variable scores. A reliability test tests the reliability, accuracy, constancy, or consistency of a measuring instrument. In this case, the measurement of reliability is used the split-half method, with the criteria that an instrument is reliable if the reliability coefficient is more than 0.700 .

\section{RESULTS AND DISCUSSION}

After the data was collected, the researchers tested the validity and reliability of the research instrument data. The results of the analysis of validity and reliability can be seen in Table 1 below:

Descriptive results as well as testing the validity and reliability of research variables as shown in table 1 below:

Tabel 1. Descriptive statistics, reliability and validity

\begin{tabular}{|l|c|c|c|c|}
\hline & Mean & Std. Dev & $\begin{array}{c}\text { Average } \\
\text { Variance } \\
\text { Extracted } \\
\text { (AVE) }\end{array}$ & $\begin{array}{c}\text { Cronbach's } \\
\text { Alpha }\end{array}$ \\
\hline Openness & 11.1898 & 1.53648 & 0,578 & 0,794 \\
\hline Empathy & 9.1314 & 2.43086 & 0,691 & 0,868 \\
\hline Supportiveness & 10.5985 & 1.80057 & 0,638 & 0,756 \\
\hline Positiveness & 12.6204 & 2.37366 & 0,567 & 0,718 \\
\hline Equality & 11.2482 & 1.73536 & 0,559 & 0,710 \\
\hline Affective & 34.5839 & 5.05651 & 0,515 & 0,843 \\
\hline
\end{tabular}


The results of the initial calculation show the AVE value $>0.5$ with a reliability value $>0.7$, so it can be said that the research instrument is valid and reliable, as shown in Table 1 above. At the same time, the results of multiple regression calculations are shown in table 2 below.

Table 2. Results of regression analysis testing

\begin{tabular}{|l|c|c|c|c|}
\hline Path & Beta & T value & P value & Conclusion \\
\hline $\begin{array}{l}\text { Openness -> } \\
\text { Affective } \\
\text { commitment }\end{array}$ & .304 & 4.060 & .000 & Accept \\
\hline $\begin{array}{l}\text { Empathy -> } \\
\text { Affective } \\
\text { commitment }\end{array}$ & .154 & 2.016 & .046 & Accept \\
\hline $\begin{array}{l}\text { Supportiveness } \\
\text {-> Affective } \\
\text { commitment }\end{array}$ & .196 & 2.648 & .009 & Accept \\
\hline $\begin{array}{l}\text { Positiveness - } \\
>\text { Affective } \\
\text { commitment }\end{array}$ & .171 & 1.999 & .048 & Accept \\
\hline $\begin{array}{l}\text { Equality -> } \\
\text { Affective } \\
\text { commitment }\end{array}$ & .196 & 2.852 & .005 & Accept \\
\hline $\begin{array}{l}\text { R2 =0,645 } \\
\text { F=47.682 }\end{array}$ & & & \\
Sig. =.000 & & & & \\
\hline
\end{tabular}

Furthermore, referring to the test results, it was found that interpersonal communication had a significant effect on affective commitment with a t-test significance value of 0.000 which was lower than the significant value of $5 \%(0.05)$. Where Openness $\rightarrow$ Affective commitment with $\mathrm{B}=0.304$ and $\mathrm{p}$ value $=0.000$, Empathy $\rightarrow$ Affective commitment with value $\mathrm{B}=.154$ and $\mathrm{p}$ value $=0.046$, Supportiveness $\rightarrow$ Affective commitment with value $\mathrm{B}=.196$ and $\mathrm{p}$ value $=0.009$, Positiveness $\rightarrow$ Affective commitment with a value of $\mathrm{B}=.171$ and $\mathrm{p}$ value $=0.048$ and Equality $\rightarrow$ Affective commitment with a value of $\mathrm{B}=.196$ and $\mathrm{p}$ value $=0.005$ so that it can be said that aspects of interpersonal communication significantly affect affective commitment. Overall the influence of interpersonal communication $=0.645$ with $p$ value $=0.000$, which indicates that $64.5 \%$ is influenced by aspects of interpersonal communication while the rest is influenced by other factors not examined in this study.

Based on the analysis that has been done, it can be concluded that interpersonal communication has a positive and significant effect on affective commitment. These results follow and confirm the hypothesis that has been described that there is an influence of interpersonal communication on affective commitment. The results of the 
study are also following relevant previous studies according to Bambacas \& Patrickson (2008); Matin, Jandaghi, Karimi \& Hamidizadeh (2010); and Postmes, Tanis, \& Wit (2001), which states that interpersonal communication has a significant effect on affective commitment.

Interpersonal communication in this study was formed based on interpersonal communication theory, according to DeVito (2013), which includes openness, empathy, supportive attitude, positive attitude, and harmony. The data processing results that have been carried out indicate that communication is in a reasonably good assessment category. This shows that interpersonal communication that occurs in private high school teachers in Palembang City is quite good. However, because the condition is still in the reasonably good category, it certainly requires some assessment indicators. These improvements are mainly in the research indicators with the lowest assessment on interpersonal communication variables, including the indicators of being a good listener and being able to control the ego in respecting the opinions of others. These two things then contribute dominantly to the assessment of empathy.

In terms of indicators, the two indicators with the highest ratings are open to receiving input and open to compromise. The open indicator in providing input shows that the private high school teachers in South Sumatra have been able to communicate openly in providing input to fellow teachers if they have ideas and ideas that can improve each other's performance. This can also indicate that the gap between teachers in communication has been overcome, and openness is also one of the characteristics of effective communication. Then on the indicator of openness in compromising, it shows an attitude of mutual understanding with each other in open communication. Openness in compromise is essential, considering that compromise in communication can reduce misunderstandings that may arise.

Openness in providing input and openness in compromise is the highest rank in assessing interpersonal communication indicators. Therefore, it can be understood that these two indicators contribute highly to assessing interpersonal communication variables. Therefore, these two indicators should be of great concern to be optimized further to increase the influence of the interpersonal communication variable.

Still, from the perspective of assessment indicators, there are two components of indicator assessment in interpersonal communication variables with the lowest assessment level. The indicator is being a good listener and controlling the ego in respecting the opinions of others. In connection with the low assessment of the indicators of being a good listener, there is still a lack of desire to understand and understand the problems or anxieties felt by others in communicating. Furthermore, the indicator of being able to control ego in respecting the opinions of others is an indication of the lack of an openminded attitude that teachers have in receiving input. They are more accustomed to providing input but are still limited in sympathy for communication with others.

The two indicators, being a good listener and being able to control the ego in respecting the opinions of others, are the lowest ranking in the assessment of indicators on 
interpersonal communication variables, so these two things need further attention to be encouraged to be better to improve the overall assessment of interpersonal communication. Next, the highest assessment of the interpersonal communication variable is openness. This assessment can mean that, in general, the openness in interpersonal communication of private high school teachers in South Sumatra is in the excellent category. Therefore, openness is a dominant factor and is an advantage in terms of interpersonal communication for private high school teachers in South Sumatra. To further improve the assessment of the openness dimension, it is necessary to increase the assessment of each indicator with the highest rating, namely being open in providing input and open in compromising, as previously explained in the indicator perspective.

The lowest dimension assessment on the interpersonal communication variable is empathy. This shows that, in general, the attitude of empathy in interpersonal communication between fellow private high school teachers in South Sumatra is still in the reasonably good category. However, this condition can indicate that empathy is still not optimal and needs more serious attention to improve it. Increasing the assessment of the empathy dimension can undoubtedly be done through an increase in the assessment indicators in it, which include being a good listener and being able to control the ego in respecting the opinions of others, as previously discussed in the indicator perspective assessment.

Furthermore, based on the results of the study, it is interpreted that the low assessment of the indicators of being a good listener and being able to control the ego in respecting the opinions of others is because teachers still have a low level of empathy between each other. In addition, teachers are also not trained in teamwork, which includes respecting other people's opinions and being good listeners. Therefore, it is necessary to increase the teamwork skills of teachers and increase their empathy through an open-minded attitude. Improvements can be made by improving communication skills through education and more effective communication training. In addition, to improve teamwork, they can be trained through Focus Group Discussions that are more effective and focused. Finally, the results of their work can be measured.

Interpersonal communication that is well established in an organization will have an impact on comfort at work. (De Nobile, 2017) Personals who are comfortable in their work environment will tend to have a higher commitment than those who are less comfortable in their work environment. In other words, interpersonal communication has an impact on commitment. The following is research that supports this. (Yao, You \& Zhu, 2020). Bambacas \& Patrickson (2008) stated that the interpersonal communication skills that enhance organizational commitment and are most valued by organizations are most lacking in managers. This paper also provides practitioners insight into the areas managers need to develop interpersonal communication skills so that their interaction with staff may enhance commitment to the organization. Matin, Jandaghi, Karimi \& Hamidizadeh (2010) stated that it identifies interpersonal communication skills that enhance organizational commitment. Research conducted by Postmes, Tanis, \& Wit 
(2001) stated that it was shown that vertical communication from senior management predicts organizational commitment best.

In contrast, commitment with the unit is predicted better by vertical communication at the level. Ghani, Zhai, Spector, Chen, Lin, Ding \& Usman (2020) revealed that the existence of harmonized information would increase individual commitment in the organization. From this opinion, it can be concluded that interpersonal communication influences affective commitment, which is relevant to previous research.

\section{CONCLUSION}

Interpersonal communication at private high school permanent teachers in Palembang City shows that interpersonal communication is in a reasonably good assessment condition. However, there are inadequate aspects such as indicators of being a good listener and being able to control ego in respecting the opinions of others. This implies that the assessment indicator is a weakness of communication. To increase the influence of interpersonal communication on affective commitment, it is necessary to improve the interpersonal communication skills of teachers, especially those related to harmony in communication, such as communication that can maintain harmony and communication that shows feelings of sharing the same fate in the same organization. Further research can also validate indicators or components of teacher affective commitment assessment that are more representative species in the characteristics of different research objects using a more significant number of samples.

\section{REFERENCES}

Ahmad, C. N. C., Shaharim, S. A., \& Abdullah, M. F. N. L. (2017). Teacher-student interactions, learning commitment, learning environment and their relationship with student learning comfort. Journal of Turkish Science Education, 14(1), 5772.

Bambacas, M., \& Patrickson, M. (2008). Interpersonal communication skills that enhance organisational commitment. Journal of Communication Management, 12(1), 5172. https://doi.org/10.1108/13632540810854235

De Nobile, J. (2017). Organisational communication and its relationships with job satisfaction and organisational commitment of primary school staff in Western Australia. Educational Psychology, 37(3), 380-398.

DeVito, J. A. (2013). Interpersonal Communication Book, The, 13/E. New York, NY: United. 
Ghani, U., Zhai, X., Spector, J. M., Chen, N. S., Lin, L., Ding, D., \& Usman, M. (2020). Knowledge hiding in higher education: Role of interactional justice and professional commitment. Higher Education, 79(2), 325-344.

Hargie, O. (2016). Skilled interpersonal communication: Research, theory and practice. Routledge.

Işik, A. N. (2020). Ethical leadership and school effectiveness: The mediating roles of affective commitment and job satisfaction. International Journal of Educational Leadership and Management, 8(1), 60-87.

Khan, A., Khan, S., Zia-Ul-Islam, S., \& Khan, M. (2017). Communication Skills of a Teacher and Its Role in the Development of the Students' Academic Success. Journal of Education and Practice, 8(1), 18-21.

Kim, K. R., \& Seo, E. H. (2018). The relationship between teacher efficacy and students' academic achievement: A meta-analysis. Social Behavior and Personality: an international journal, 46(4), 529-540.

Matin, H. Z., Jandaghi, G., Karimi, F. H., \& Hamidizadeh, A. (2010). Relationship between interpersonal communication skills and organizational commitment (Case Study: Jahad Keshavarzi and University of Qom, Iran). European Journal of Social Sciences, 13(3), 387-398.

Meyer, J., \& Allen, N. J. (2001). Organizational commitment. Personnel psychology and human resource management: A reader for students and practitioners, 289-342.

Muhonen, H., Pakarinen, E., Poikkeus, A. M., Lerkkanen, M. K., \& Rasku-Puttonen, H. (2018). Quality of educational dialogue and association with students' academic performance. Learning and Instruction, 55, 67-79. https://doi.org/10.1016/j.learninstruc.2017.09.007

Postmes, T., Tanis, M., \& De Wit, B. (2001). Communication and commitment in organizations: A social identity approach. Group processes \& intergroup relations, 4(3), 227-246.

Schatz-Oppenheimer, O. (2017). Being a mentor: novice teachers' mentors' conceptions of mentoring prior to training. Professional Development in Education, 43(2), 274-292.

Sidharta, I., \& Affandi, A. (2016). The empirical study on intellectual capital approach toward financial performance on rural banking sectors in Indonesia. International Journal of Economics and Financial Issues, 6(3), 1247-1253.

Yao, J., You, Y., \& Zhu, J. (2020). Principal-teacher management communication and teachers' job performance: the mediating role of psychological empowerment and affective commitment. The Asia-Pacific Education Researcher, 29(4), 365-375. 